\title{
Paravasation with Cyclophosphamide - Case Report of Tissue Necrosis in a Patient with Primary Breast Cancer
}

\author{
Julia K. Jueckstock loannis Mylonas Barbara Strobl Fritz Willgeroth Harald L. Sommer \\ Klaus Friese
}

First Department of Obstetrics and Gynecology, Ludwig-Maximilians University Munich, Germany

\section{Keywords}

Paravasation · Cyclophosphamide · Chemotherapy

\section{Summary}

Background: Paravasation is a rare but severe complication of treatment with cytotoxic agents. Some anticancer drugs are considered to be of high toxicity (vesicant), some are merely irritant, and some are regarded as nearly non-toxic to healthy tissue as is the case with cyclophosphamide. Case Report: In this report, we present the first case of severe tissue damage caused by a paravasation of cyclophosphamide in a breast cancer patient receiving chemotherapy. Conclusion: Therefore, every attending oncological physician should be aware of the possibility of severe tissue damage as a consequence of cyclophosphamide paravasation.

\section{Introduction}

Today, it is the standard of care for many cancer patients to receive chemotherapy in oncological outpatient clinics in an ambulant setting. To standardize treatment procedures, distinct guidelines exist in various hospitals all over the world $[1,2]$. The aim of these guidelines, besides the safe administration of toxic medical agents, is the prevention as well as the correct and effective handling of incidents such as paravasation [3]. However, these are no validated principles but are rather based on empiric data and results from animal models [2].

Paravasation is a rare but severe complication of treatment with cytotoxic agents. The frequency of paravasation events is estimated to be between 0.6 and $6 \%$ [1]. Training of both the

\author{
Schlüsselwörter \\ Paravasat · Cyclophosphamid · Chemotherapie
}

\section{Zusammenfassung}

Hintergrund: Paravasate sind seltene aber bedrohliche Komplikationen einer chemotherapeutischen Therapie mit Zytostatika. Einige Chemotherapeutika haben eine hohe Toxizität (gewebsnekrotisierende Zytostatika), manche dagegen nur eine gewebsreizende Wirkung. Cyclophosphamid gilt als ein nicht-gewebsreizendes Chemotherapeutikum. Fallbericht: In diesem Fallbericht wird zum ersten Mal ein Fall mit einer bedrohlichen Gewebsnekrose nach einem Paravasat mit Cyclophosphamid bei einer Patientin mit Mammakarzinom vorgestellt. Schlussfolgerung: Jeder praktisch onkologisch tätige Arzt sollte mit der potentiell gewebsnekrotisierenden Wirkung eines Paravasats mit Cyclophosphamid vertraut sein.

nursing staff and the attending oncologists is very important to minimize the incidence of iatrogenic patient injury [3]. Therefore, in the event of extravasation of chemotherapeutic drugs, every oncological staff member who is in contact with the patient should know how to react. Emergency treatment procedures vary and depend on the characteristics of the antineoplastic agent administered [4].

While the toxicity of vesicant agents (e.g. vinca alkaloid derivatives and anthracyclines) in healthy tissues is relatively high, cyclophosphamide is considered a comparatively non-toxic drug [5]. However, in this report, we describe a case of severe tissue damage due to paravasation of cyclophosphamide in order to alert every attending oncological physician to the potential toxicity of this cytotoxic agent.

\begin{tabular}{ll}
\hline KARGER & @ 2007 S. Karger GmbH, Freiburg \\
Fax +497614520714 & Accessible online at: \\
$\begin{array}{l}\text { E-mail Information@Karger.de } \\
\text { www.karger.com }\end{array}$ & www.karger.com/onk
\end{tabular}




\section{Case Report}

A 50-year-old, gravida 3, para 3 woman was admitted to our hospital with recently diagnosed primary breast cancer. Skin-sparing mastectomy [6] with immediate reconstruction and sentinel lymph node biopsy had been performed at a district hospital near her hometown several weeks ago. The histopathological stage of the tumor was pT1c (m), pN0 (0/1sn), G3. For adjuvant cytotoxic treatment, the patient had decided to come to our hospital. Therefore, the planned procedures were discussed with her in detail, and she gave written informed consent to participate in the adjuvant SUCCESS trial. The antineoplastic regimen in this study comprises 3 cycles of FEC (5-fluorouracil $500 \mathrm{mg} / \mathrm{m}^{2}$, epirubicin $100 \mathrm{mg} / \mathrm{m}^{2}$, cyclophosphamide $500 \mathrm{mg} / \mathrm{m}^{2}$ ) followed by 3 cycles of Doc (docetaxel $100 \mathrm{mg} / \mathrm{m}^{2}$ ) mono vs. DocGem (docetaxel $75 \mathrm{mg} / \mathrm{m}^{2}$ combined with gemcitabine $1,000 \mathrm{mg} / \mathrm{m}^{2}$ ) [7].

Having accomplished all required preliminary examinations, the patient received the first chemotherapy cycle at our oncological outpatient department. After administration of the entire doses of 5-FU and epirubicin, we checked the position of the peripheral venous access and administered approximately $50 \mathrm{ml}$ of sodium chloride $(\mathrm{NaCl})$ solution as is common standard in our hospital. After ensuring that the venous access was placed correctly and there were no signs of extravasation, we started the application of cyclophosphamide. Near the end of the cyclophosphamide infusion, the patient presented with pain and a tumescence on her left forearm, seemingly caused by paravasation. The infusion was stopped immediately, and supportive counteractive measures were taken: An attempt was made to remove the medication by aspiration from the site on the forearm where the peripheral venous access was located. This was, however, unsuccessful, so the extremity was cooled and placed in an ele vated position. The patient was kept under observation for several hours by the end of which she showed no pain, loss of function or any other visible abnormalities on her arm or hand. She left the hospital intending to return the next day for check-up. The following day, she presented with a swollen and edematous forearm but still without pain. However, 1 day later, the patient developed a searing pain in her forearm and wrist and was referred to a team of hand surgeons who administered pain medication and symptomatically treated the arm and wrist by applying a heparin ointment and fitting a splint. Chemotherapy was temporarily stopped, and the patient returned periodically for check-ups.

Nearly 1 month after the event, the ailment deteriorated, and 2 whitish lesions became visible on the back of the patient's hand (figs. 1a, b), suspicious of a beginning necrosis correspondent to a grade $3 \mathrm{NCI}$ common toxicity criteria lesion, (grade 4 according to GOG common toxicity criteria) [8]. Thus, the symptomatic treatment was continued. During the next few months, the subjective and objective problems decreased but an induration and paresthesis on the left hand and forearm persisted (figs. 1c-f). In addition, loss of both muscular strength and sensibility was observed.

\section{Discussion}

Even if the administration of cytotoxic agents is performed optimally and with the utmost care, the risk of paravasation is always present [1]. However, it is important to differentiate between iatrogenic complications and local adverse reactions caused by the chemotherapeutic substance itself (e.g. thrombophlebitis or a so-called recall reaction) [1,9]. A simple method to reduce the risk of paravasation is to implant a central venous device (Port or Hickman catheter) [1].

Analyses in cancer patients showed that paravasation of vesicant antineoplastic agents, such as anthracyclines or vinca

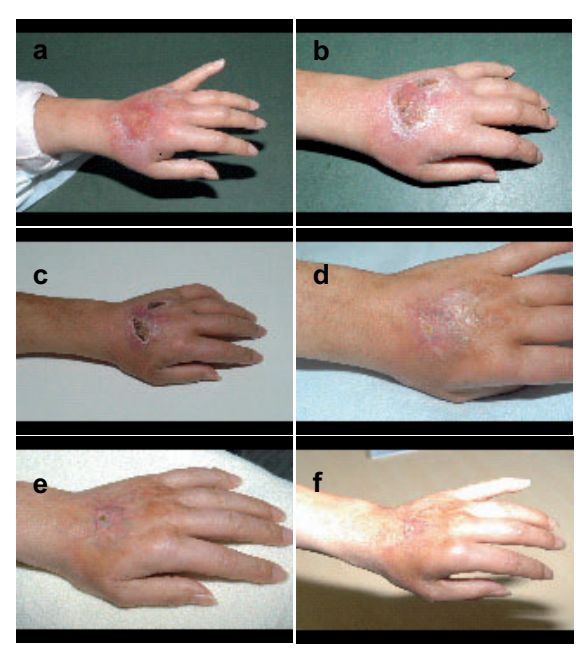

alkaloid derivatives, cause severe damage to healthy tissue in up to $30 \%$ [10]. Goolsby et al. [4] describe binding of the cytotoxic agent to specific cell structures thereby causing cell death as a major mechanism of tissue damage following extravasation. Scarring, atrophy, and chronic pain can result. When paravasation occurs while irritant cytotoxic agents, such as carboplatin or docetaxel, are administered, no necrosis will be seen [3]. Thus, in the event of paravasation with these kinds of anticancer drugs, certain procedures to minimize the damage have to be performed immediately [11], even if the patient shows no symptoms [2]. However, these guidelines are merely empiric due to a lack of prospective clinical investigations: i) The infusion should be stopped at once. ii) As much of the medication as possible should be removed by aspiration with a syringe. iii) The affected area should be cooled unless vinca alkaloid drugs have been administered in which case it should be kept warm (e.g. by application of warm compresses) [2]. The underlying effect of the cooling procedure is vasoconstriction and thus inhibition of diffusion of the toxic agents into the healthy tissue. On the other hand, the purpose of heat treatment is to increase blood circulation and thus induce dilution of the toxic agent to make it less harmful [3]. iv) All undertaken procedures and applied measures have to be documented very carefully. v) Vital signs (pulse, blood pressure) should be checked every $30 \mathrm{~min}$, and the patient should stay under strict surveillance for several weeks. vi) In cases of severe tissue damage such as distinct necrosis or ulceration, surgical methods have to be applied, whereas in most cases, conservative treatment is sufficient [12]. vii) It is also of great importance to instruct the patient to perform home self-care after an extravasation incident [2]. Today, the standard of care includes a number of antidotes which can be used to prevent severe tissue damage: DMSO ( $99 \%$ solution) is indicated for treatment of paravasation incidents with anthracyclines, mitomycin $\mathrm{C}$, and platinum compounds for up to 14 days. Hyalurinodase can be used for topical treatment of extravasation of vinca alkaloid drugs [13]. In 
the case of doxorubicin paravasation, dexrazoxane $(1,000$ $\mathrm{mg} / \mathrm{m}^{2}$ ) should be applied 3 times within $36 \mathrm{~h}[2,14]$. Corticosteroids as well as sodium bicarbonate are no longer recommended [1].

In contrast, cyclophosphamide, a non-irritant drug, is known to be less toxic in healthy tissues. Hence, in the event of paravasation, it is recommended to merely stop the infusion immediately, remove as much of the substance as possible, and cool the affected area while immobilizing the extremity [5]. No case of injury caused by paravasation of cyclophosphamide has been reported in the literature so far. Nevertheless, in our case report, the patient suffered necrosis with consecutive atrophy and chronic pain. Thus, we suggest that the large quantity of cyclophosphamide that extravasated into her forearm caused these major complications. At the same time, despite all retaliatory measures taken, the cytotoxic agent must have travelled from the patient's forearm to the back of her hand and cumulated there. Probably due to the high tissue concentration of the antineoplastic drug in our case, cyclophosphamide showed a so far unknown toxicity causing necrosis and subsequent chronic pain and loss of function. Therefore, this cytotoxic agent must not be considered safe and non-toxic but potentially noxious and even vesicant depending on the amount and tissue concentration of the extravasated drug.

In conclusion, every attending oncologist should be aware of the possibility of severe tissue damage due to paravasation of cyclophosphamide. Since no specific antidote is known for this cytotoxic agent yet, further investigation is needed to reveal the toxic mechanisms of this drug when cumulated in healthy tissue. A better understanding of the underlying tissue damaging processes may subsequently lead to the development of effective treatment and thus help preventing such severe complications of cyclophosphamide paravasation.

\section{References}

1 Jordan K, Grothe W, Schmoll HJ: Extravasation of chemotherapeutic agents: prevention and therapy. Dtsch Med Wochenschr 2005;130:33-37.

2 Guideline Comprehensive Cancer Centre Ulm, Germany (CCCU), 18.02. 2005, pp. 75-79.

3 Adami NP, de Gutierrez MG, da Fonseca SM, de Almeida EP: Risk management of extravasation of cytostatic drugs at the adult chemotherapy outpatient clinic of a university hospital. J Clin Nurs 2005;14:876-882.

4 Goolsby TV, Lombardo FA: Extravasation of chemotherapeutic agents: prevention and treatment. Semin Oncol 2006;33:139-143.

5 Fachinformation Endoxan ${ }^{\circledR}$, Stand: Januar 2005. www.baxter.de/downloads/fachinformation/ endoxan/endoxan.pdf

6 Dian D, Hemminger G, Janni W, Friese K, Janicke F: Management of skin-sparing mastectomy: results of a survey of German hospitals. Onkologie 2006; 29:267-270
7 Reich B: Individualisierte Mammakarzinomtherapie mit Gemcitabin - länger und besser leben. Onkologie 2007;30:70-71.

8 Cancer Therapy Evaluation Program, Common Terminology Criteria for Adverse Events, Version 3.0. DCTD, NCI, NIH, DHHS. March 31, 2003 (http://ctep.cancer.gov), publish date: August 9, 2006.

9 Kodym E, Kalinska R, Ehringfeld C, SterbikLamina A, Kodym R, Hohenberg G: Frequency of radiation recall dermatitis in adult cancer patients. Onkologie 2005;28:18-21.

10 Boyle DM: Documentation and outcomes of advanced nursing practice. Oncol Nurs Forum 1995; 22:11-17.

11 Dorr RT: Antidotes to vesicant chemotherapy extravasations. Blood Rev 1990;4:41-60.
12 Tsavaris NB, Karagiaouris P, Tzannou I, Komitsopoulou P, Bacoyiannis C, Karabellis A, Papanicolaou V, Mylonakis N, Karvounis N, Zoannou A, et al.: Conservative approach to the treatment of chemotherapy-induced extravasation. J Dermatol Surg Oncol 1990;16:519-522.

13 Bertelli G, Gozza A, Forno GB, Vidili MG, Silvestro S, Venturini M, Del Mastro L, Garrone O, Rosso R, Dini D: Topical dimethylsulfoxide for the prevention of soft tissue injury after extravasation of vesicant cytotoxic drugs: a prospective clinical study. J Clin Oncol 1995;13:2851-2855.

14 Frost A, Gmehling D, Azemar M, Unger C, Mross $\mathrm{K}$ : Treatment of anthracycline extravasation with dexrazoxane - clinical experience. Onkologie 2006 29:314-318. 